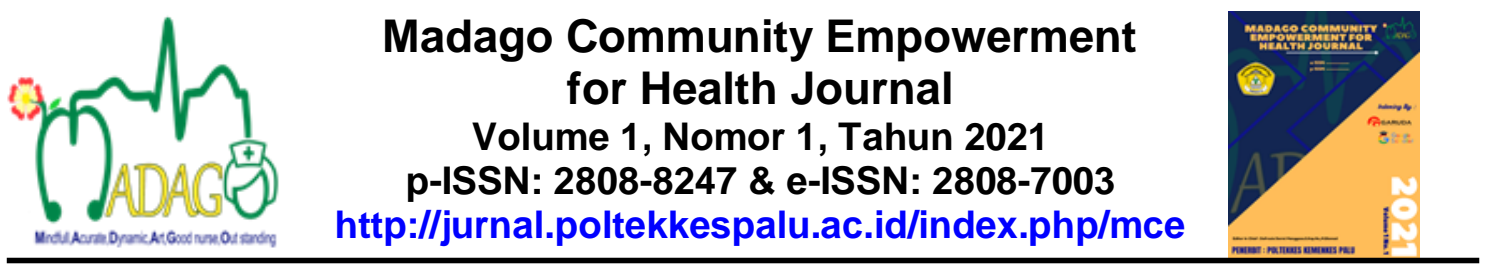

\title{
Edukasi Persiapan Persalinan yang Aman di Era Covid-19
}

\section{Education for Safe Delivery Preparation in the Covid-19 Era}

\author{
${ }^{1)}$ Dyah Ayu Hardayanti", 1)Kadar Ramadhan $\mathbb{} \square$, 2)Dewi Nurviana Suharto $\mathbb{D}$, \\ 2)Agusrianto \\ ${ }^{1}$ Program Studi D-III Kebidanan Poso, Poltekkes Kemenkes Palu \\ ${ }^{2}$ Program Studi D-III Keperawatan Poso, Poltekkes Kemenkes Palu \\ 凹Email: kadarlaure@gmail.com
}

\begin{abstract}
ABSTRAK
Proses persiapan persalinan merupakan suatu proses dimana seorang lbu yang menanti kelahiran si buah hati yang selama ini dinantikan. Persiapan persalinan dapat dilakukan dengan cara mempersiapkan diri dengan berbagai informasi tentang hal-hal yang menyangkut persalinan, terutama dimasa pandemi saat ini. Ibu hamil pasti akan merasa cemas dan khawatir dalam menghadapi proses kelahiran, sehingga perlu mempersiapkan ibu hamil melalui proses persalinan dengan aman di masa pandemi COVID-19. Tujuan kegiatan pengabdian kepada masyarakat ini yaitu agar ibu lebih siap dan siaga saat proses kelahiran walaupun pada masa pandemi. Metode pengabdian masyarakat yaitu dengan memberikan penyuluhan kepada seorang ibu hamil di desa Matako. Hasil pengabdian menunjukkan bahwa terdapat peningkatan pengetahuan tentang proses persiapan persalinan yang aman di era COVID-19. Kami menyarankan kepada ibu hamil untuk melakukan vaksinasi, mengurangi aktivitas di luar, dan terus menerapkan protokol kesehatan jika mengharuskan beraktivitas di luar rumah.
\end{abstract}

Kata Kunci: Covid-19, Persalinan, Pandemi.

\section{ABSTRACT}

The process of preparing for childbirth is a process in which a mother awaits the birth of the child she has been waiting for. Preparation for childbirth can be done by preparing yourself with various information about matters relating to childbirth, especially during the current pandemic. Pregnant women will definitely feel anxious and worried in the face of the birth process, so it is necessary to prepare pregnant women through the delivery process safely during the COVID-19 pandemic. The purpose of this community service activity is to make mothers more prepared and alert during the birth process even during the pandemic. The method of community service is by providing counseling to a pregnant woman in the village of Matako. The results of the service show that there is an increase in knowledge about the process of preparing for safe childbirth in the COVID19 era. We advise pregnant women to vaccinate, reduce outdoor activities, and continue to apply health protocols if they require activities outside the home.

Keywords: Covid-19, Childbirth, Pandemic

Copyright (c) 2021 DOI: http://doi.org/10.33860/mce.v1i1.660

Received: 19-10-2021; Accepted: 30-10-2021; Published: 31-10-2021 


\section{PENDAHULUAN}

Sejak Desember 2019, infeksi virus corona baru (COVID-19) telah berkembang pesat (World Health Organization, 2021) dan berdasarkan pengalaman yang diperoleh dari wabah virus corona sebelumnya, ibu hamil merupakan kelompok rentan terhadap virus ini (Jamieson et al., 2009). Ibu hamil yang terinfeksi atau dicurigai terinfeksi COVID-19 memiliki risiko yang tinggi untuk mengalami masalah dalam persalinan (Qi et al., 2020). Kehamilan adalah waktu yang sangat istimewa dalam kehidupan seorang wanita dan keluarganya, namun menjalaninya di tengah pandemi bisa sangat menegangkan dan membuat ibu stress (UNICEF, 2021).

Pada tahun 2018, terdapat 76\% kematian ibu terjadi di fase persalinan dan pasca persalinan dimanai $24 \%$ terjadi saat hamil, $36 \%$ saat persalinan dan $40 \%$ pasca persalinan. Saat Pandemi Covid-19, kenaikan jumlah Kematian Ibu juga terjadi. Per 14 September 2021, sebanyak 1086 ibu meninggal dengan hasil positif berdasarkan pemeriksaan swab PCR/antigen (Kementerian Kesehatan R.I., 2021). AKI pada era Covid-19 meningkat karena terdapat 18-20\% kematian ibu karena Covid-19, selain itu terdapat sebanyak 51,9\% ibu hamil positif tanpa gejala dari 536 ibu hamil. Dengan adanya Covud-19, program penurunan angka kematian ibu hamil terkendala (Bona, 2021).

Dalam menjalani proses persalinan, seorang ibu harus mempersiapkan diri. Tidak sedikit ibu yang mengalami kecemasan dalam menghadapi persalinan (Siregar et al., 2021). Dengan adanya pandemik, kecemasan ibu hamil makin meningkat (Tantona, 2019; Viandika \& Septiasari, 2021; Zainiyah \& Susanti, 2020). Persiapan persalinan merupakan bagian terpenting dari proses persalinan persalinan yang untuk meningkatkan kesehatan optimal menjelang persalinan, terutama untuk mengurangi kecemasan dan membuat ibu lebih tenang (Lucia et al., 2015; Nurdianti, 2017)

Salah satu masalah dalam persiapan persalinan di era Covid-19 adalah kurangnya edukasi yang diperoleh oleh ibu hamil. Selain itu cakupan vaksinasi yang masih rendah. Tujuan kegiatan ini adalah untuk meningkatkan pengetahuan lbu tentang persiapan persalinan yang harus dilakukan saat menjelang persalinan di masa pandemik Covid-19.

\section{METODE}

Kegiatan ini merupakan bagian dari Praktik Keluarga Binaan yang diselenggarakan oleh Prodi D-III Kebidanan Poso, Poltekkes Kemenkes Palu. Kegiatan ini dilakukan di Desa Matako pada 17 september 2021, sasarannya adalah seorang Ibu hamil. Kegiatan pengabdian ini diawali dengan pembagian kuesioner (pre-test) sebelum dilakukan penyuluhan, selanjutnya dilakukan pembagian leaflet penyuluhan dan dilanjutkan dengan memberikan penyuluhan mengenai proses persiapan persalinan yang aman di era COVID-19. Evaluasi dilakukan dengan memberikan kuesioner (post-test) untuk mengevaluasi 
pengetahuan Ibu. evaluasi dilakukan ketika selesai penyuluhan, sekitar 30 menit setelah penyuluhan.

\section{HASIL DAN PEMBAHASAN}

Pelaksanaan kegiatan ini menerapkan protokol kesehatan pandemik COVID-19. TIM pengabdi dan peserta wajib menggunakan masker dan sebisa mungkin menjaga jarak. Tempat pelaksanaan di rumah peserta Kegiatan dimulai dengan pembagian kuesioner pre-test seperti terlihat pada Gambar 1. Setelah pengisian selesai maka dilanjutkan dengan pemberian penyuluhan menggunakan media leaflet seperti terlihat pada Gambar 2.

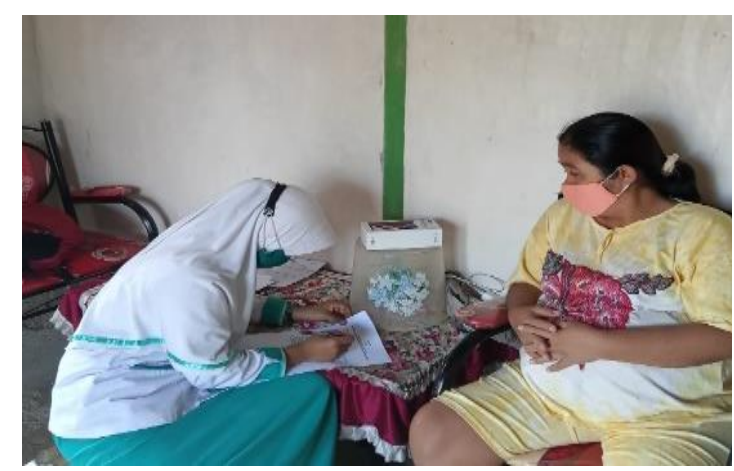

Gambar 1. Pengisian Pretest

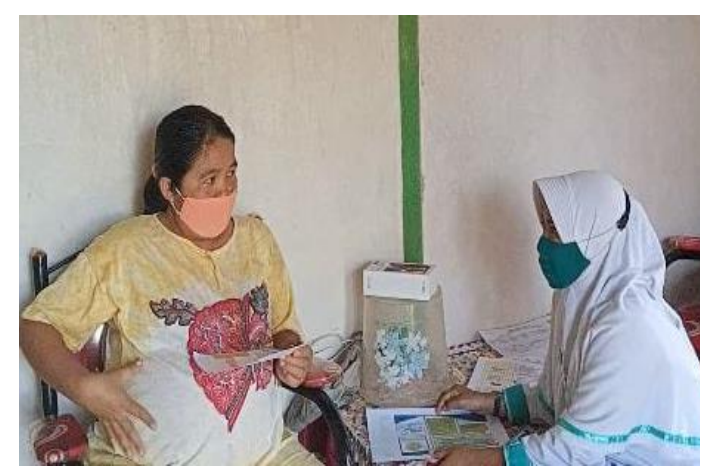

Gambar 2 Pemberian penyuluhan

Penyuluhan tentang proses persiapan persalinan yang aman di era Covid19 dilakukan melalui pemberian leaflet lalu memberikan kuesioner 10 soal tentang persiapan persalinan. Hal yang disampaikan kepada ibu hamil terkait dengan pentingnya menerapkan protokol kesehatan yang ketat berupa memakai masker, menjaga jarak dan menghindari kerumunan jika sedang berada di luar. Hal lain juga mengenai vaksinasi ibu hamil. Berdasarkan penelitian yang telah dilakukan, kesediaan masyarakat umum di Sulawesi Tengah untuk divaksinasi hanya 35\% (Ichsan et al., 2021), sehingga perlu upaya dari bidan untuk terus memberikan edukasi kepada ibu hamil agar mau divaksinasi .

Secara umum melalui kegiatan ini, terdapat kenaikan pengetahuan dari $60 \%$ ke $90 \%$ setelah penyuluhan. Oleh karena itu penyuluhan tentang proses persiapan persalinan yang aman di era Covid-19 dilakukan agar bisa mencegah terjangkitnya virus covid-19 dapat kita lihat bersama pada diagram di bawah ini: 


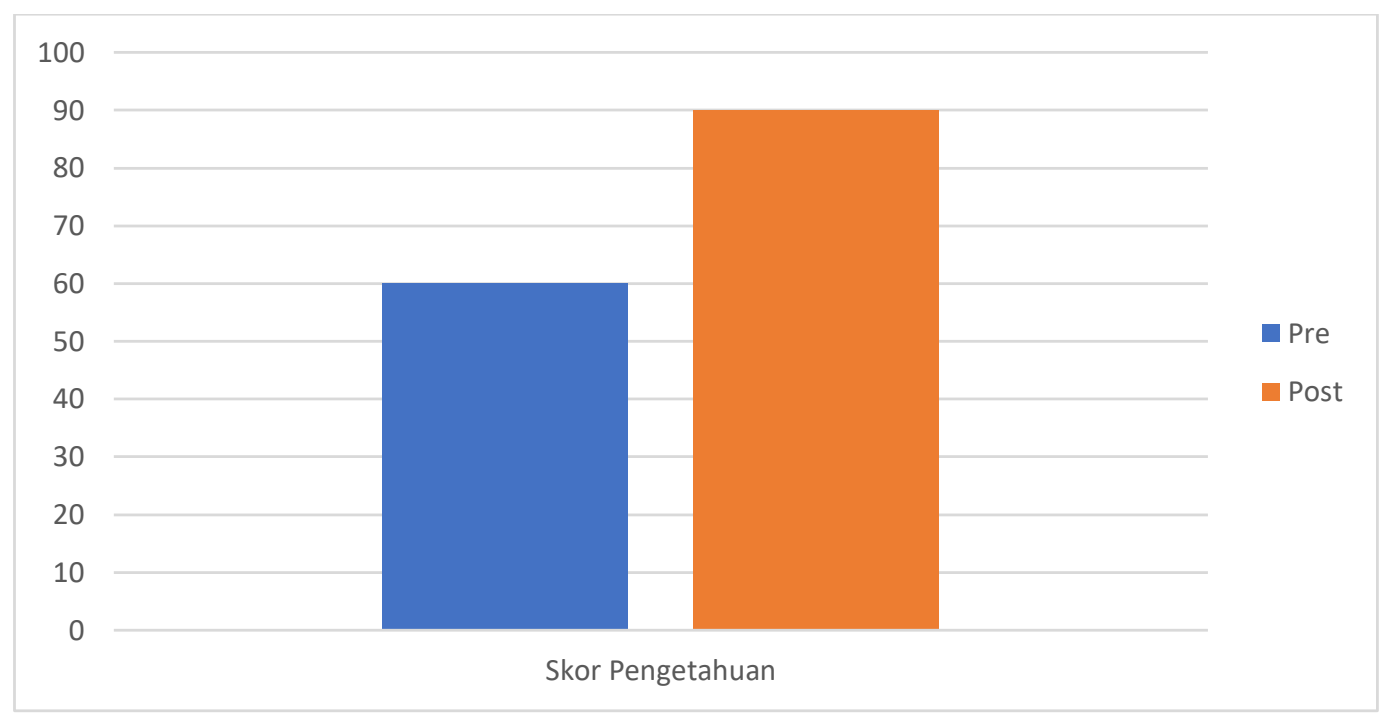

Gambar 3 Grafik Peningkatan pengetahuan

Diagram Pre dan Post Penyuluhan Persiapan Persalinan di Desa Matako. Dari Diagram diatas dapat di ketahui bersama bahwa terdapat perbedaan pengetahuan setelah dilakukan penyuluhan tentang Persiapan Persalinan di era pandemic COVID-19. Dari grafik 1 menunjukkan bahwa setelah dilakukan penyuluhan peserta pengabdian sudah memahami apa yang perlu dipersiapkan untuk menjalani persalinan di era pandemik COVID-19, pengabdian yang telah dilakukan telah berhasil meningkatkan pengetahuan lbu hamil tentang persiapan persalinan.

\section{SIMPULAN DAN SARAN}

Berdasarkan hasil pelaksanaan kegiatan, dapat disimpulkan adanya peningkatan pengetahuan ibu hamil tentang proses persiapan persalinan yang aman di era Covid-19 sesudah penyuluhan, dilihat dari hasil evaluasi melalui pengisian kuesioner. Kami menyarankan kepada ibu hamil untuk mengurangi aktivitas di luar, dan terus menerapkan protokol kesehatan jika mengharuskan beraktivitas di luar rumah.

\section{DAFTAR PUSTAKA}

Bona, M. F. (2021). 18\% Kematian Ibu Hamil Terjadi Karena Covid-19. Beritasatu.Com. https://www.beritasatu.com/kesehatan/807633/18kematian-ibu-hamil-terjadi-karena-covid19

Ichsan, D. S., Hafid, F., Ramadhan, K., \& Taqwin, T. (2021). Determinan Kesediaan Masyarakat menerima Vaksinasi Covid-19 di Sulawesi Tengah. Poltekita: Jurnal IImu Kesehatan, 15(1), 1-11. https://doi.org/10.33860/jik.v15i1.430

Jamieson, D. J., Honein, M. A., Rasmussen, S. A., Williams, J. L., Swerdlow, D. L., Biggerstaff, M. S., Lindstrom, S., Louie, J. K., Christ, C. M., Bohm, S. R., Fonseca, V. P., Ritger, K. A., Kuhles, D. J., Eggers, P., Bruce, H., Davidson, 
H. A., Lutterloh, E., Harris, M. L., Burke, C., ... Olsen, S. J. (2009). H1N1 2009 influenza virus infection during pregnancy in the USA. The Lancet, 374(9688), 451-458. https://doi.org/10.1016/S0140-6736(09)61304-0

Kementerian Kesehatan R.I. (2021). Kemenkes Perkuat Upaya Penyelamatan Ibu dan Bayi. Kemkes.Go.Id. https://sehatnegeriku.kemkes.go.id/baca/umum/20210914/3738491/kemen kes-perkuat-upaya-penyelamatan-ibu-dan-bayi/

Lucia, S., Purwandari, A., \& Pesak, E. (2015). Pengaruh Pelaksanaan Kelas lbu Hamil Terhadap Pengetahuan Tentang Persiapan Persalinan. Jurnal IImiah Bidan, $\quad 3(1), \quad 91266 . \quad$ https://ejurnal.poltekkesmanado.ac.id/index.php/jidan/article/view/361

Nurdianti, D. (2017). Hubungan Dukungan Keluarga Pada Ibu Hamil Trimester III Dengan Persiapan Persalinan. Jurnal Kebidanan UMTAS, 1, 36-43. https://umtas.ac.id/journal/index.php/bimtas/article/download/491/283/1695

Qi, H., Luo, X., Zheng, Y., Zhang, H., Li, J., Zou, L., Feng, L., Chen, D., Shi, Y., Tong, C., \& Baker, P. (2020). Safe delivery for pregnancies affected by COVID-19. BJOG: An International Journal of Obstetrics \& Gynaecology, 127(8), 927-929. https://doi.org/10.1111/1471-0528.16231

Siregar, N. Y., Kias, C. F., Nurfatimah, N., Noya, F., Longgupa, L. W., Entoh, C., \& Ramadhan, K. (2021). Tingkat Kecemasan Ibu Hamil Trimester III dalam Menghadapi Persalinan. Jurnal Bidan Cerdas, 3(1), 18-24. https://doi.org/10.33860/jbc.v3i1.131

Tantona, M. D. (2019). Anxiety Disorders In Pregnant Women During Covid-19 Pandemic. Jurnal Penelitian Perawat Profesional, 2(4), 381-392. https://doi.org/10.37287/jppp.v2i4.181

UNICEF. (2021). COVID-19 and pregnancy: Staying safe, giving birth and getting vaccinated. Unicef.Org. https://www.unicef.org/rosa/stories/covid-19-andpregnancy

Viandika, N., \& Septiasari, R. M. (2021). Anxiety in Pregnant Women During Pandemic Covid-19. Jurnal Keperawatan Jiwa (JKJ): Persatuan Perawat Nasional Indonesia, 9(1), 135-142. https://jurnal.unimus.ac.id/index.php/JKJ/article/view/6907

World Health Organization. (2021). Clinical management Clinical management Living guidance COVID-19 (Issue January). WHO Press. https://www.who.int/publications/i/item/WHO-2019-nCoV-clinical-2021-1

Zainiyah, Z., \& Susanti, E. (2020). Anxiety in Pregnant Women During Coronavirus (Covid-19) Pandemic in East Java, Indonesia. Majalah Kedokteran Bandung, 52(3), 149-153. https://doi.org/10.15395/mkb.v52n3.2043 